\title{
Suppression of the transcription factor MSX1 gene delays bovine preimplantation embryo development in vitro
}

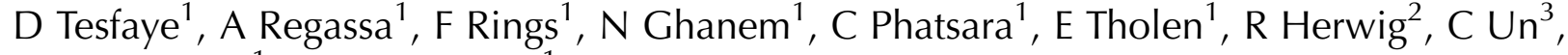 \\ K Schellander ${ }^{1}$ and $M$ Hoelker ${ }^{1}$ \\ ${ }^{1}$ Animal Breeding and Husbandry Group, Institute of Animal Science, University of Bonn, Endenicher Allee 15, \\ 53115 Bonn, Germany, ${ }^{2}$ Department of Vertebrate Genomics, Max Planck Institute for Molecular Genetics, \\ Ihnestrasse 63-73, 14195 Berlin, Germany and ${ }^{3}$ Department of Biology, Faculty of Science and Arts, Yildiz Technical \\ University, 34349 Istanbul, Turkey
}

Correspondence should be addressed to D Tesfaye; Email: tesfaye@itw.uni-bonn.de

D Tesfaye and A Regassa contributed equally to this work

\begin{abstract}
This study was conducted to investigate the effect of suppressing transcription factor gene MSX1 on the development of in vitro produced bovine oocytes and embryos, and identify its potential target genes regulated by this gene. Injection of long double-stranded RNA (LdsRNA) and small interfering RNA (siRNA) at germinal vesicle stage oocyte reduced MSX1 mRNA expression by 73 and $37 \%$ respectively at metaphase II stage compared with non-injected controls. Similarly, injection of the same anti-sense oligomers at zygote stage reduced MSX1 mRNA expression by 52 and 33\% at 8-cell stage compared with non-injected controls. Protein expression was also reduced in LdsRNA- and siRNA-injected groups compared with non-injected controls at both stages. Blastocysts rates were $33,28,20$ and $18 \%$ in noninjected control, scrambled RNA (scRNA), LdsRNA- and siRNA-injected groups respectively. Cleavage rates were also significantly reduced in Smartpool siRNA (SpsiRNA)-injected group (53.76\%) compared with scRNA-injected group (57.76\%) and non-injected control group $(61 \%)$. Large-scale gene expression analysis showed that 135 genes were differentially regulated in SpsiRNA-injected group compared with non-injected controls, of which 54 and 81 were down- and up-regulated respectively due to suppression of MSX1. Additionally, sequence homology mapping and gene enrichment analysis with known human pathway information identified several functional modules that were affected due to suppression of MSX1. In conclusion, suppression of MSX1 affects oocyte maturation, embryo cleavage rate and the expression of several genes, suggesting its potential role in the development of bovine preimplantation embryos. Reproduction (2010) 139 857-870
\end{abstract}

\section{Introduction}

The MSX family genes are one of the most highly conserved homeobox-containing genes that are identified in several animal species. The three mammalian members, MSX1, MSX2 and MSX3, share 98\% homology in their protein domain (Davidson \& Hill 1991, Davidson 1995). They play important roles in inductive tissue interactions during vertebrate organogenesis, and their differential expression mediates patterning, morphogenesis and tissue formation (Chen et al. 1996, Bendall \& Abate-Shen 2000). They encode closely related homeoproteins that function as transcriptional repressors through interacting with the components of the core transcription complex as well as other homeoproteins (Catron et al. 1996), and promote apoptosis in developing limbs and cephalic neural crest (Song et al. 1992, Graham et al. 1993, 1994, 1996, Davidson 1995, Marazzi et al. 1997, Gomes \& Kessler 2001).
Although it is expressed in diverse tissues, MSX1 gene expression is mainly associated with multi-potent progenitor cell (Bendall \& Abate-Shen 2000). It is strongly expressed in a region of highly proliferative, multi-potent cells that give rise to chondrogenic and osteogenic derivatives of the limb but absent in regions where cells stopped to proliferate and begun to undergo differentiation (Bendall \& Abate-Shen 2000). MSX1 is also expressed at high levels in adult mouse uterine epithelium and decreases during pregnancy following embryonic implantation to regulate various aspects of uterine epithelial morphology and maintain the adult uterus in a morphogenetically and developmentally responsive state (Pavlova et al. 1994). It is detected at lower level in endometrium and placentomes particularly after 60 days of gestation in cows (Ishiwata et al. 2003).

In our recent study, we found higher expression of MSX1 in bovine oocytes that were derived from subordinate follicles of the dominance phase of the 
first follicular wave compared with oocytes derived from the growth phase (Ghanem et al. 2007). We also found relatively higher abundance of $M S X 1$ transcript in embryo biopsies derived from blastocysts that resulted in no pregnancy compared with blastocysts that resulted in successful calf delivery after transfer to recipients (El-Sayed et al. 2006). On the other hand, higher expression of MSX1 was reported in developmentally competent bovine oocytes (Donnison \& Pfeffer 2004) and blastocysts (Lazzari et al. 2006). This shows the lack of clear relationship between the expression of MSX1 and developmental potential of bovine oocytes and embryos. Therefore, we aimed to investigate the role of MSX1 in the development of preimplantation bovine embryos especially in regulating the expression of developmentally important genes by suppressing its transcript during bovine oocyte maturation and cleavage stage embryo development.

\section{Results}

\section{Expression profiling of MSX1 in bovine preimplantation embryos}

To get an insight into its preimplantation expression profile, we analysed MSX1 expression across different stages of bovine preimplantation embryo development. The analysis showed that it is highly expressed at germinal vesicle (GV) stage oocyte followed by a moderate expression at metaphase II (MII) stage oocyte. Its expression level starts to decline sharply from zygote up to 8-cell stage and diminishes starting from morula stage onwards (Fig. 1).

\section{Experiment 1: suppression of MSX1 during bovine oocyte maturation}

In this experiment, MSX1 long double-stranded RNA (LdsRNA), small interfering RNA (siRNA) and scrambled RNA (scRNA) were microinjected at GV stage oocytes after partial removal of cumulus cells. Expression analysis of the target mRNA in MII oocytes $28 \mathrm{~h}$ post microinjection showed that injection of MSX1 LdsRNA and siRNA at GV stage oocyte reduced the mRNA

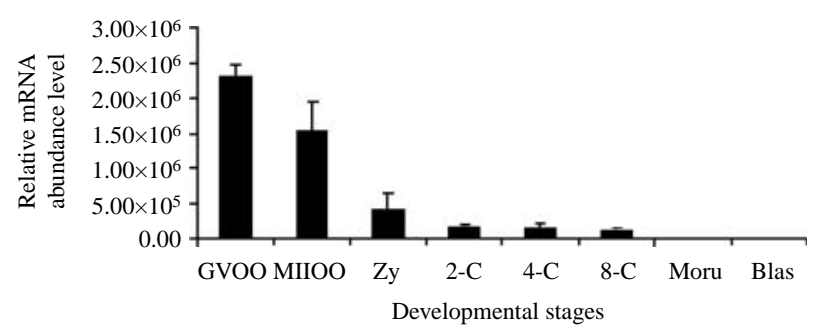

Figure 1 Expression profiling showing bovine MSX1 mRNA at different stages of preimplantation development. GVOO, germinal vesicle oocytes; MIIOO, metaphase II oocytes; Zy, zygotes; 2-C, two cells; 4-C, four cells; 8-C, eight cells; Moru, morula; Blas, blastocysts.

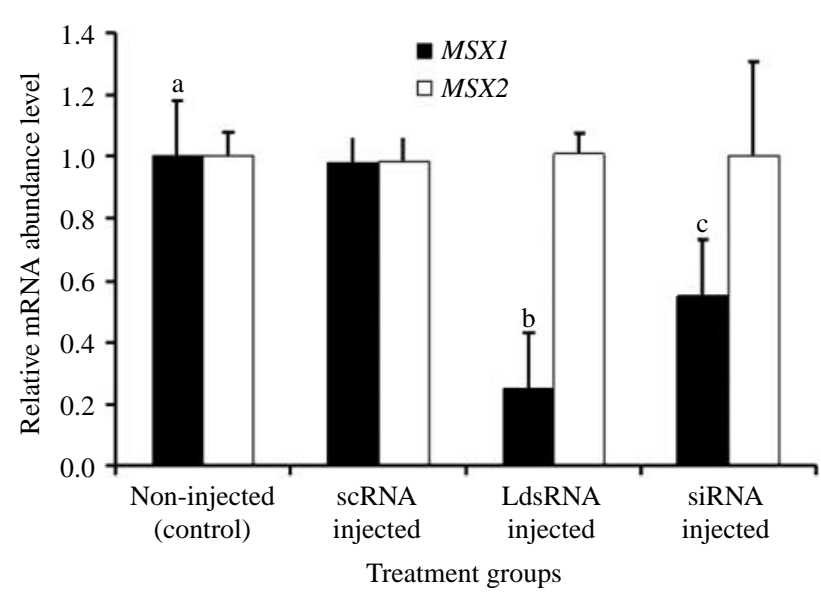

Figure 2 Relative abundances of $M S X 1$ and MSX2 mRNAs (mean \pm S.E.M.) at MII oocytes from different treatment groups after microinjection at GV stage. Bars with different letters, a, b and c, are significantly different $(P<0.05)$.

expression levels by 73 and $37 \%$ respectively at MII stage compared with non-injected controls (Fig. 2).

In order to confirm the sequence-specific suppression of LdsRNA and siRNA, the mRNA expression level of a closely related transcript, bovine $M S X 2$, was quantified using the same samples that were used to quantify MSX1 mRNA. The expression data showed that there was no reduction in the level of MSX2 mRNA in either case (Fig. 2).

The protein expression analysis indicated subsequent reduction in the expression of the target MSX1 protein at MII oocyte stage (Fig. 3) compared with non-injected controls.

About 27, 25 and $26 \%$ of oocytes from scRNA, LdsRNA and siRNA treatment groups respectively did not survive the physical injuries due to microinjection procedure as determined $2-3 \mathrm{~h}$ post injection. However, these differences are not statistically significant. Although statistically not significant, the percentage of oocytes that reached MII stage was higher in noninjected controls $(80.87 \%)$ and scRNA-injected $(79.47 \%)$ groups compared with those injected with LdsRNA (73.75\%) and siRNA (75\%; Table 1).

\section{Experiment 2: suppression of MSX1 retards the development of cleavage stage embryos}

In this experiment, microinjection of scRNA, LdsRNA and siRNA was performed at zygote stage, and the effects were assessed at different preimplantation developmental stages. As in experiment 1, about 21, 23 and $24 \%$ of the zygotes from scRNA, LdsRNA and siRNA treatment groups respectively did not survive the physical injuries during microinjections. However, these differences are not significant. Microinjection of LdsRNA and siRNA at zygote stage reduced the mRNA expression levels by 52 and $33 \%$ at the 8 -cell stage 


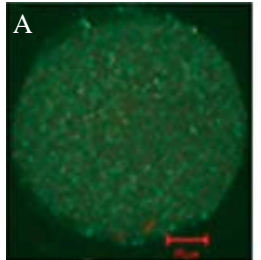

Immature oocyte before injection

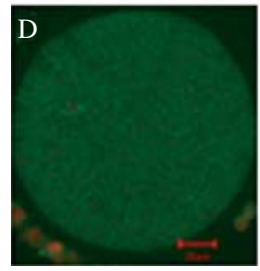

Matured oocyte injected with LdsRNA

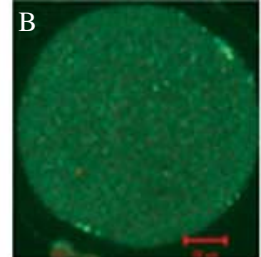

Matured oocyte uninjected

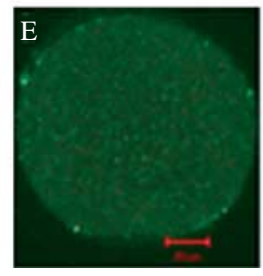

Matured oocyte injected with siRNA

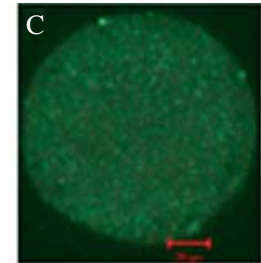

Matured oocyte injected with scRNA

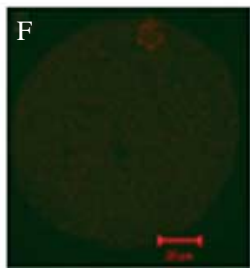

Negative control
Figure 3 Representative immunostained MII oocytes from different treatment groups showing MSX1 protein abundance levels as recorded from the emission of green fluorescence signal. Oocytes in the microinjection groups were injected at GV stage, and the resulting protein expression was assessed at MII stage. Panels A-E show GV oocyte at the time of injection, non-injected oocyte, oocytes that were injected with scRNA, LdsRNA and siRNA respectively. Panel F shows a negative control staining that was incubated only with secondary antibody with out the use of primary antibody. Scale bars below each image represent $20 \mu \mathrm{m}$.

compared with non-injected control (Fig. 4). As in experiment 1, to confirm the gene-specific suppression due to injection of LdsRNA and siRNA a closely related bovine transcript, MSX2 was quantified at 8-cell stage embryos, and no effect on the expression level of this transcript was observed at both developmental stages (Fig. 4).

In order to study the effects of suppressing MSX1 mRNA on protein expression, 2-, 4- and 8-cell stage embryos from all treatment groups were immunostained using rabbit anti-human polyclonal MSX1 primary antibody. As shown in Fig. 5, reduction in the protein expression as estimated from the intensity of florescence signal was observed in embryos that were treated with LdsRNA and siRNA compared with non-injected control and scRNA-injected groups.

Table 1 Percentage of oocytes (mean \pm S.E.M.) that survived the physical injuries during microinjection and formed polar body after 24-h culture in different treatment groups. Numbers in the parentheses indicate the number of oocytes that survived mechanical injury during microinjection and formed polar bodies out of the total number of injected oocytes.

\begin{tabular}{lccc}
\hline Treatment & $\begin{array}{c}\text { Number } \\
\text { of oocytes }\end{array}$ & Survival rate & $\begin{array}{c}\text { Extrusion of } \\
\text { polar bodies }\end{array}$ \\
\hline Non-injected & 298 & $100.00 \pm 0.0(298)$ & $80.87 \pm 1.91(241)$ \\
scRNA injected & 367 & $73.02 \pm 2.52(268)$ & $79.47 \pm 3.00(213)$ \\
LdsRNA injected & 376 & $75.00 \pm 1.92(282)$ & $73.75 \pm 2.13(208)$ \\
siRNA injected & 367 & $74.11 \pm 8.18(272)$ & $75.00 \pm 1.91(204)$ \\
\hline
\end{tabular}

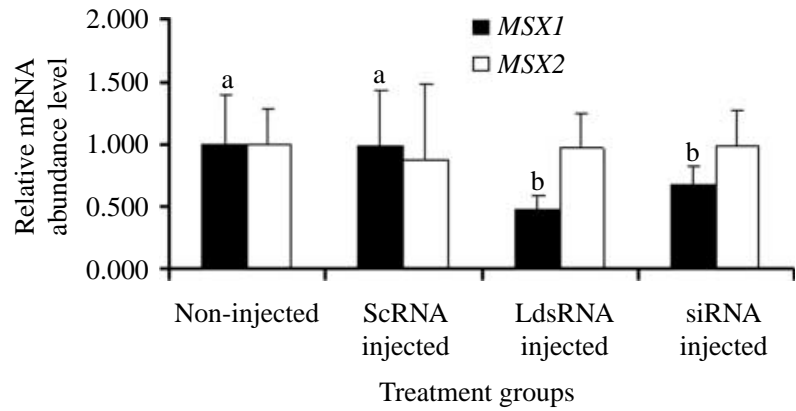

Figure 4 Relative $M S X 1$ and $M S X 2$ mRNA abundance levels (mean \pm S.E.M.) of 8-cell stage embryos from different treatment groups. Bars with different letters, $\mathrm{a}$ and $\mathrm{b}$, are significantly different $(P<0.05)$.

The proportions of 2-, 4- and 8-cell stage embryos were determined at $72 \mathrm{~h}$ post insemination (hpi) to estimate cleavage rates (Table 2). No significant differences were observed in the cleavage rates of zygotes until 4-cell stage but higher proportion of zygotes $(P \leq 0.05)$ from noninjected control group developed to 8-cell stage compared with those injected with LdsRNA and siRNA. Further observation of embryonic development beyond 8-cell stage until day 8 blastocyst stage showed that zygotes injected with LdsRNA and siRNA developed at a lower rate to the blastocysts stage compared with scRNA-injected group and non-injected controls (Table 3). While 61 and $56 \%$ of the 8-cell embryos from non-injected controls and scRNA-injected groups respectively reached blastocysts stage, 50 and $47 \%$ of embryos from LdsRNA- and siRNAinjected groups respectively reached the same stage.

\section{Experiment 3: suppression of MSX1 resulted in differential expression of developmentally important genes at the time of maternal to embryonic genome transition}

In this experiment, Smartpool siRNAs (SpsiRNAs) consisting of four pools of siRNAs (Dharmacon, Inc., Chicago, IL, USA) were used to suppress MSX1 and investigate the effect on the development of preimplantation embryos and target genes. Three pools of zygotes were injected with SpsiRNAs and scRNA, and relative MSX1 mRNA abundance and their cleavage rates were compared with non-injected control. Injection of SpsiRNAs resulted in a $40 \%$ reduction in $M S X 1$ transcript abundance as shown in Fig. 6. Similar to LdsRNA and siRNA, suppression of MSX1 due to injection of SpsiRNAs reduced cleavage rates as significantly lower $53.76 \%$ of embryos from this group reached 8-cell stage compared with 61 and $57.76 \%$ of embryos from non-injected and scRNAinjected groups respectively (Table 4).

Following this, two groups including zygotes injected with SpsiRNAs and non-injected controls were used to analyse differential gene expression due to suppression of MSX1. Eight-cell stage embryos from SpsiRNAinjected groups were compared with non-injected 


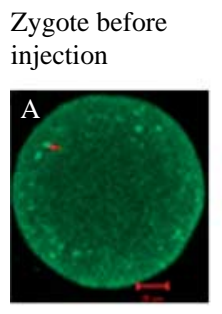

Negative control
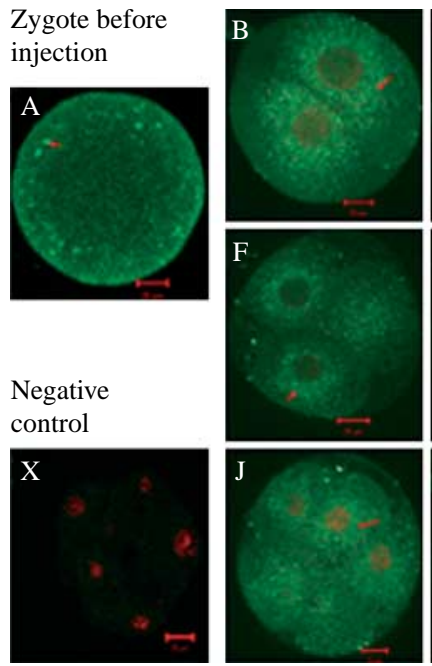

Uninjected (control)
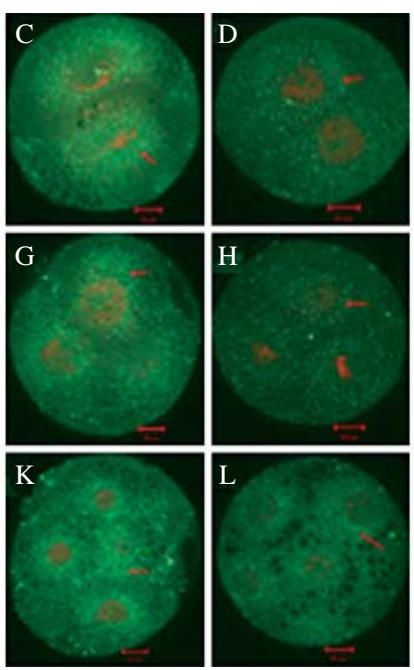

Injected with scRNA

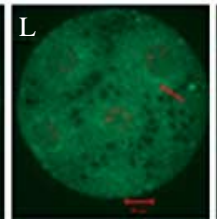

Injected with LdsRNA

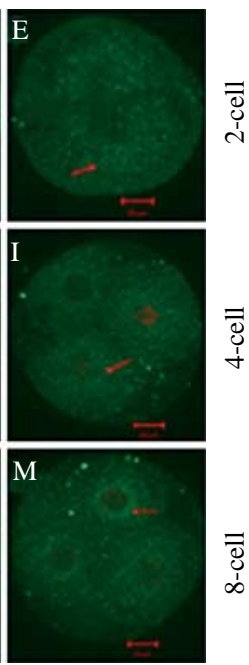

Injected with siRNA
Figure 5 Representative immunostained embryos from different treatment groups showing MSX1 protein abundance levels recorded from the emission of green fluorescence signal. Embryos in the microinjection groups were injected at zygote stage, and the resulting protein expression was assessed at 8 -cell stage. Panels $A-M$ show zygote before injection, non-injected embryos and embryos injected with scRNA, LdsRNA and siRNA at 2-, 4- and 8-cell stage respectively and negative control staining.

controls by hybridising with a bovine cDNA array. Each comparison was done using six independent hybridizations including dye-swap. Analysis of the array data revealed that 135 genes were differentially expressed in SpsiRNA-injected group compared with non-injected controls, of which 54 and 81 were down- and up-regulated respectively due to suppression of MSX1 (Supplementary Tables 1 and 2, see section on supplementary data given at the end of this article). The hierarchical clustering and heat map of those differentially regulated genes is indicated in Fig. 7. Gene ontology terms (molecular functions and biological processes) showing the proportion of differentially expressed genes due to suppression of MSX1 are presented in Figs 8 and 9.

Another three pools of $(n=60)$ 8-cell embryos were used for total RNA isolation, CDNA synthesis and realtime qRT-PCR validation of the array data. The results of the analysis showing that real-time qRT-PCR validation of the array data has confirmed the expression pattern of four out of seven transcripts are in accordance with the microarray result. However, the fold change difference obtained by qRT-PCR validation is slightly lower than the array result (Fig. 10).

In order to identify functional modules related to MSX 1 target genes, we carried out enrichment analysis using a comprehensive database resource (http://cpdb. molgen.mpg.de). In CPDB, twelve different pathways and interaction databases are integrated by identifier mapping (Kamburov et al. 2009). Using this integrated content, we generated gene sets (neighbourhood-based entity sets, NESTs) that are related via functional interactions. Enrichment of MSX1 target genes with respect to these gene sets was judged by $P$ values computed from the hypergeometric distribution. A total of 135 bovine genes show significant changes with respect to the SpsiRNAs, of which 97 had a human homolog and 57 of these genes can be mapped to the known functional interactions. Figure 11 shows two NESTs enriched by MSX1 target genes.

\section{Discussion}

Despite previous studies in mouse models, the role of MSX1 in the development of bovine preimplantation embryo is poorly understood. Here, we showed that suppression of MSX1 transcript and protein impaired the development of bovine oocytes and embryos through

Table 2 Percentage of zygotes (mean \pm s.E.M.) that reached different developmental stages by $72 \mathrm{~h}$ post insemination. Zygotes were injected with long double-stranded RNA (LdsRNA), small interfering RNA (siRNA) and scrambled RNA (scRNA), and their development was compared with noninjected controls. Numbers in the parentheses indicate the number of zygotes that survived mechanical injury during microinjection, not cleaved, reached 2-, 4- and 8-cell stages out of the total number of injected zygotes.

\begin{tabular}{|c|c|c|c|c|c|c|c|}
\hline Treatment & $\begin{array}{c}\text { Number } \\
\text { of zygotes }\end{array}$ & Survival rate & $\begin{array}{l}\text { Non-cleaved } \\
\text { zygotes }\end{array}$ & 2-Cell stage & 4-Cell stage & 8-Cell stage & Cleavage rate \\
\hline Non-injected & 445 & $100.0 \pm 0(445)$ & $20.16 \pm 2.63(89)$ & $10.69 \pm 1.91(47)$ & $13.88 \pm 1.51(62)$ & $54.44 \pm 4.36^{\mathrm{a}}(247)$ & $79.01 \pm 2.59$ \\
\hline scRNA injected & 652 & $79.14 \pm 4.74(513)$ & $21.24 \pm 1.62(109)$ & $13.25 \pm 2.69(66)$ & $15.78 \pm 1.53(81)$ & $49.70 \pm 2.80^{\mathrm{a}, \mathrm{b}}(255)$ & $78.73 \pm 2.35$ \\
\hline LdsRNA injected & 636 & $76.51 \pm 5.38(485)$ & $29.66 \pm 4.38(137)$ & $13.02 \pm 1.53(64)$ & $18.25 \pm 2.18(90)$ & $39.05 \pm 2.59^{b}(194)$ & $70.32 \pm 2.1$ \\
\hline siRNA injected & 619 & $76.03 \pm 4.67(470)$ & $33.20 \pm 3.86(153)$ & $14.57 \pm 2.42(68)$ & $11.25 \pm 3.20(54)$ & $40.96 \pm 3.45^{\mathrm{b}, \mathrm{c}}(195)$ & $66.780 \pm 3.02$ \\
\hline
\end{tabular}

Means with in a column followed by different superscripts are significantly different $(P \leq 0.05)$. 
Table 3 Percentage of zygotes (mean \pm s.E.M.) that reached 8-cell stage at $72 \mathrm{hpi}$ and blastocyst stage at 8 days post insemination. Zygotes were injected with long double-stranded RNA (LdsRNA), small interfering RNA (siRNA) and scrambled RNA (scRNA), and their development was compared with non-injected controls. Numbers in the parentheses indicate the number of zygotes that reached 8-cell and blastocyst stages out of the total number of injected zygotes.

\begin{tabular}{lclcr}
\hline Treatment & $\begin{array}{c}\text { Number } \\
\text { of zygotes }\end{array}$ & Proportion of 8 cells & Blastocysts rate & $\begin{array}{c}\text { Blastocysts to } \\
\mathbf{8} \text { cells ratio }\end{array}$ \\
\hline Non-injected & 222 & $54.50 \pm 4.12^{\mathrm{a}}(121)$ & $33.35 \pm 2.6^{\mathrm{a}}(74)$ & 0.61 \\
scRNA injected & 282 & $49.64 \pm 2.64^{\mathrm{a}, \mathrm{b}}(140)$ & $27.93 \pm 1.74^{\mathrm{a}}(71)$ & 0.56 \\
LdsRNA injected & 274 & $39.41 \pm 2.53^{\mathrm{b}}(108)$ & $19.65 \pm 3.49^{\mathrm{b}}(49)$ & 0.50 \\
siRNA injected & 253 & $38.87 \pm 3.23^{\mathrm{b}}(98)$ & $18.27 \pm 2.96^{\mathrm{b}}(47)$ & 0.47 \\
\hline
\end{tabular}

Means with in a column followed by different superscripts are significantly different $(P \leq 0.05)$.

affecting different developmental phenotypes. We investigated the effects of suppressing MSX1 transcript and protein on oocyte maturation, development to $2-$, 4 - and 8-cells, blastocysts and differential expression of downstream genes.

Extrusion of polar body is the measure of oocyte developmental competence as those oocytes have matured nucleus, develop to MII meiotic division (Kruip et al. 1983, Sato et al. 1990, Luther et al. 2005, Pant et al. 2005) and are more fertile (Xu \& Greve 1988, Plachot \& Mandelbaum 1990, Bao et al. 2002). Reduced oocyte maturation in association with polar body extrusion was also reported by Kruip et al. (1983), where formation of polar bodies was observed only in oocytes that were microscopically assessed during 19-25 h post LH peak level compared with those assessed earlier. Delayed extrusion of polar bodies as a function of maturation due to suppression of MSX1 in the present study could provide evidence that MSX1 has a role in the development of bovine preimplantation embryos and supports the findings of the study where it was highly expressed in developmentally competent oocytes (Donnison \& Pfeffer 2004).

The efficacy of suppressing the targeted transcripts in mammalian oocytes and embryos appears to determine the extent of change in developmental phenotype. Suppression of developmentally important gene delays cellular growth (El-bashir et al. 2001). Accordingly, suppression of $M S X 1$ reduced the number of zygotes that developed to 8-cell and blastocyst stages, and this can be explained by the dependence of early preimplantation bovine embryos on maternally derived and accumulated transcripts and proteins until the onset of major

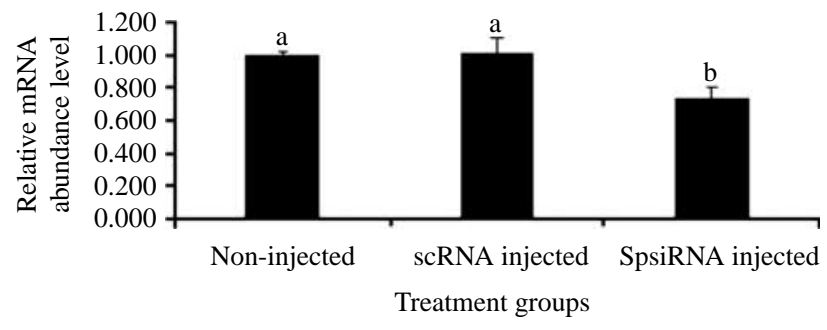

Figure 6 Relative MSX1 mRNA expression levels of zygotes injected with SpsiRNA and scRNA compared with non-injected controls. Bars with different letters, $a$ and $b$, are significantly different $(P<0.05)$. embryonic genome activation (Telford et al. 1990, Memili et al. 1998, Memili \& First 1999, 2000). Thus, the significant difference among zygotes from the controls and LdsRNA- and siRNA-injected groups in developing to 8-cell stage and the small differences among the groups regarding early cleavage rates might be explained by the beneficial effects of maternally accumulated transcripts and proteins during oocyte maturation and their persistent activity until the onset of major embryonic genome activation (Davidson 1986, Eyestone \& First 1986, Frei et al. 1989, Kopency et al. 1989) and to the temporal variation in mRNA and protein turn over rates (Li et al. 2004). We propose that the accumulated MSX1 transcript and protein are used by the embryos in the LdsRNA- and siRNA-injected groups to undergo normal early cleavage but their cleavage is reduced due to further depletion of the respective transcript and protein at latter stages. Phenotypic data, particularly those related to development to 8-cell and blastocyst stages, suggest that MSX1 expression is required for the development of preimplantation bovine embryos particularly during maternal to embryonic genome transition.

Injections of MSX1 LdsRNA and siRNA at GV stage oocyte and zygote stages resulted in the sequencespecific degradation of the target message at MII oocyte and 8-cell stages. Relatively higher suppression was recorded for LdsRNA at MII oocyte compared with the 8-cell stage (Figs 2 and 4). This difference might be associated with the observed differences in the abundance of MSX1 transcript (Fig. 1) at these stages as the abundance of the target transcript greatly affects RNAimediated suppression efficiency (Hu et al. 2004, Tesfaye et al. 2007). Similarly, there were differences in suppression efficiencies between LdsRNA and siRNA at the same stage, and this might be due to the difference in the inherent suppression efficacies of the two RNAs which in turn depends on variation in the corresponding RNA sequences (Holen et al. 2002). Reduction in the protein expression of the groups injected with LdsRNA and siRNA compared with the controls could also be due to the RNAi effect that leads to degradation of the endogenous complementary mRNA or blockage of ribosomal movement along the native mRNA to halt 
Table 4 Percentage of zygotes (mean \pm S.E.M.) that reached different developmental stages at 72 hpi. Numbers in the parenthesis indicate the number of zygotes that survived mechanical injury during microinjection, not cleaved, reached 2-, 4- and 8-cell stages out of the total number of injected zygotes.

\begin{tabular}{|c|c|c|c|c|c|c|c|}
\hline Treatment & $\begin{array}{c}\text { Number } \\
\text { of zygotes }\end{array}$ & Survival rate & $\begin{array}{l}\text { Non-cleaved } \\
\text { zygotes }\end{array}$ & 2-Cell stage & 4-Cell stage & 8-Cell stage & Cleavage rate \\
\hline Non-injected & 479 & $100.0 \pm 0(479)$ & $18.14 \pm 1.36(89)$ & $7.40 \pm 2.23(37)$ & $12.20 \pm 1.16(61)$ & $61.04 \pm 2.11^{\mathrm{a}}(292)$ & $81.84 \pm 1.35^{\mathrm{a}}$ \\
\hline scRNA injected & 497 & $85.35 \pm 5.65(427)$ & $21.66 \pm 1.37(92)$ & $7.45 \pm 1.16$ & $13.11 \pm 0.84(56)$ & $57.76 \pm 0.96^{\mathrm{a}, \mathrm{b}}(246)$ & $78.63 \pm 1.47^{\mathrm{a}, \mathrm{b}}$ \\
\hline SpsiRNA injected & 653 & $83.03 \pm 2.94(540)$ & $24.58 \pm 2.31$ (135) & $5.62 \pm 1.46(32)$ & $15.78 \pm 2.03(86)$ & $53.76 \pm 2.38^{\mathrm{b}}(287)$ & $75.42 \pm 2.31^{\mathrm{b}}$ \\
\hline
\end{tabular}

Means with in a column followed by different superscripts are significantly different $(P<0.05)$.

translation and eventually blocks protein synthesis via introduction of dsRNAs into the cell (Fire et al. 1998).

Transcription factors are proteins involved in the regulation of gene expression through binding to the promoter elements upstream of genes and either facilitate or inhibit their transcription. As a transcription factor, the protein of $M S X 1$ orchestrates gene expression and regulates cell growth, proliferation, differentiation, cell-to-cell communication and the apoptotic pathway during pattern formation in vertebrate embryogenesis (Song et al. 1992, Graham et al. 1993, 1994, Davidson 1995, Chen et al. 1996, Marazzi et al. 1997, Bendall \& Abate-Shen 2000, Gomes \& Kessler 2001). In support of this notion, a number of developmentally important genes were down-regulated due to suppression of MSX1. These include bone morphogenetic protein 15 (BMP15), various forms of zinc finger proteins (ZNF43, ZNF85 and ZNF91), rio kinase 3 (RIOK3), general transcription factor IIA, 1-like $(A L F)$, aurora kinase A (AURKA), pituitary tumour transforming gene 1 (PTTG1), Bos taurus elongation factor $1 \alpha(E E F 1 A 1)$ and others.

A maternal transcript, BMP15, along with growth and differentiation factor 9 , regulates follicular development in rodents, sheep and humans (Elvin et al. 2000, McNatty et al. 2003, Di Pasquale et al. 2004, Shimasaki et al. 2004) and ovulation rate in sheep (Davis et al. 1991, Galloway et al. 2000, Hanrahan et al. 2004, Juengel et al. 2004). It has been detected at higher level in bovine oocytes that were derived from the dominance phase of follicular development where MSX1 has been found to be up-regulated (Ghanem et al. 2007) suggesting that the two genes are operating in the same signalling pathway and involve in the development of bovine preimplantation embryos.

Under expression of transcripts such as ZNF proteins, RIOK3, ALF and AURKA due to suppression of MSX1 might evidence that these genes are the downstream effectors of MSX1 effects as both of them are involved in the biology of oocytes. For instance, ZNF proteins are involved in a DNA-dependent regulation of transcription, and RIOK3 plays a role in the process of chromosome segregation and amino acid phosphorylation. Both chromosome segregation and protein phosphorylation are among the processes that are critically required during oocyte maturation. ALF encodes a germ cell-specific counterpart of the large $(\alpha / \beta)$ subunit of general transcription factor, and is involved in Xenopus oocyte maturation (Han et al. 2003). AURKA has been suggested to be involved in the maturation of bovine oocytes (Vigneron et al. 2004).

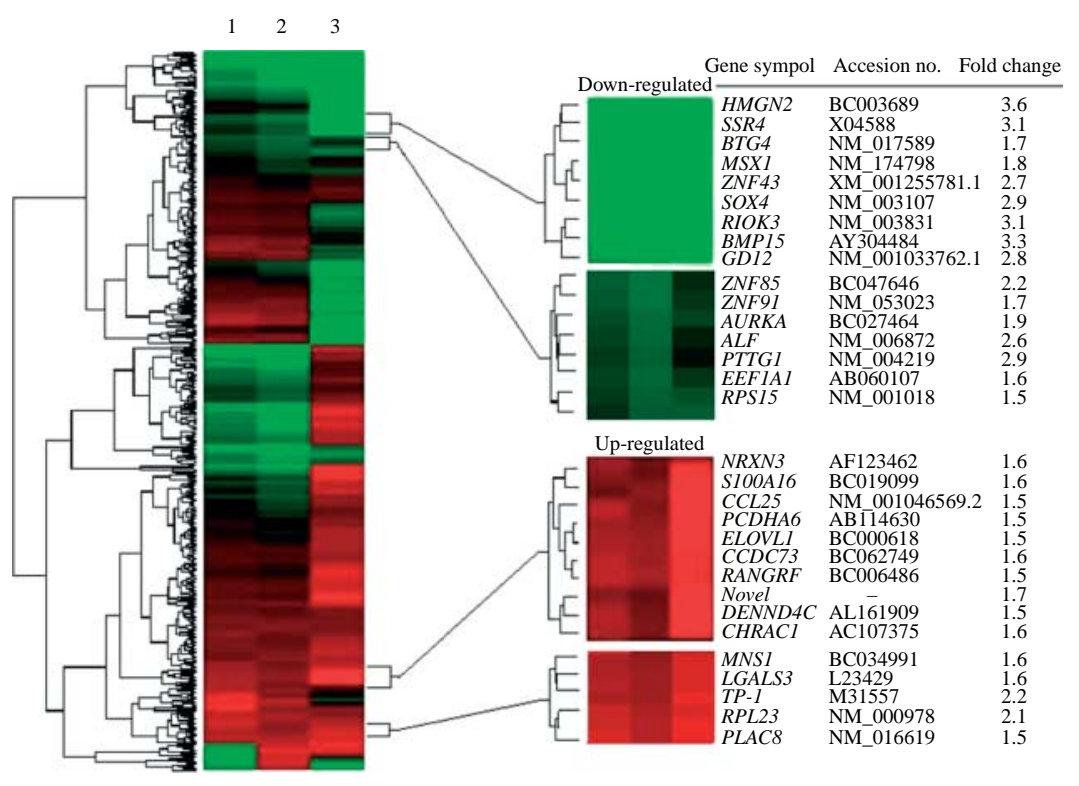

Figure 7 Heat map and list of some differentially regulated genes at 8 -cell stage embryos due to suppression of MSX1. The red and green blocks represent the up- and down-regulated genes respectively. 

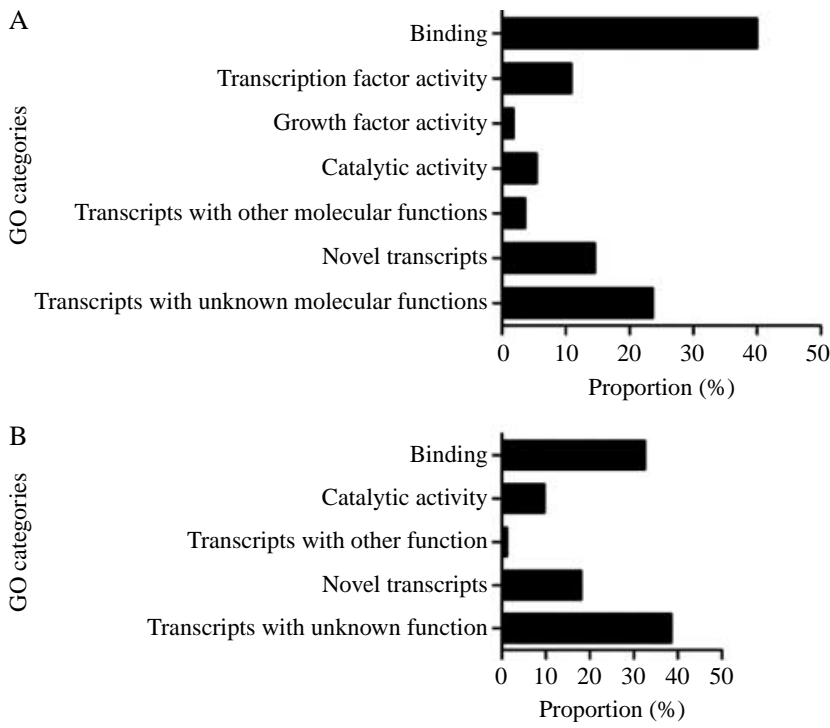

Figure $8 \mathrm{GO}$ terms (molecular function) categories of down-regulated genes (A) and up-regulated genes (B) due to suppression of MSX1 in 8-cell stage embryos.

It encodes a protein that is involved in microtubule formation and/or stabilization at the spindle pole during chromosome segregation and regulates the centrosome and mitotic microtubules in mammals (Udayakumar et al. 2006). It is also believed to be involved in mitotic controls (Prigent \& Giet 2003).

PTTG1 has been indicated to exhibit properties of a global transcription factor and specifically modulates the $\mathrm{G}_{1} / \mathrm{S}$-phase transition. It has been detected at higher level in murine zygote than in oocyte suggesting its possible role in zygotic genome activation (Yao et al. 2003). Results from our recent studies indicated that
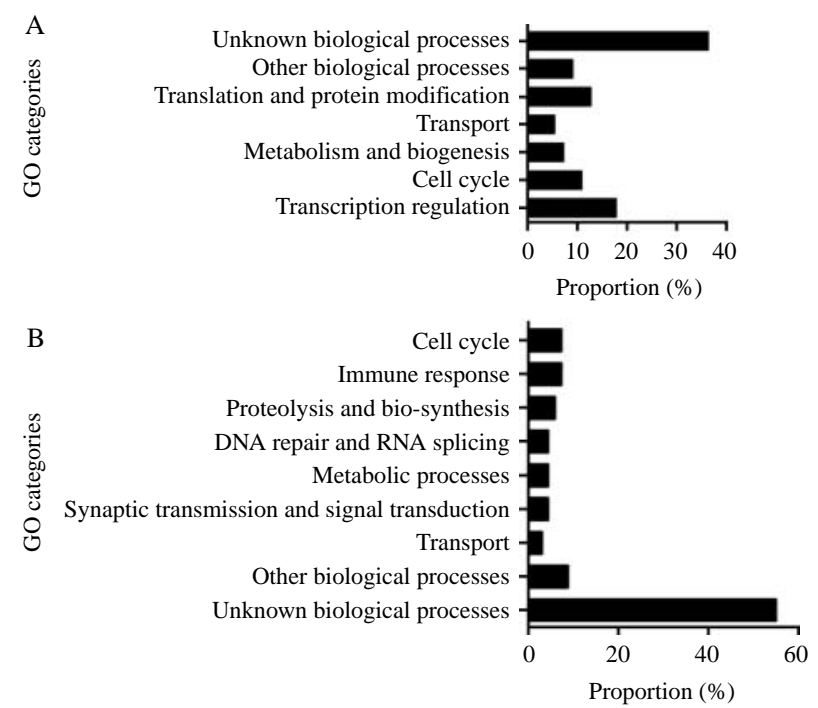

Figure 9 GO terms (biological process) categories of down-regulated genes (A) and up regulated genes (B) due to suppression of MSX1 in 8-cell stage embryos.
PTTG1 has the same expression pattern as MSX1 (El-Sayed et al. 2006, Ghanem et al. 2007), and its involvement in apoptosis and zygotic genome activation (Hamid \& Kakar 2004) might indicate its association with MSX1 during embryonic patterning. EEF1A1 encodes a ubiquitous protein which is involved in the elongation step of protein synthesis and catalyzes the binding of aminoacyl-tRNA to the ribosome (Merrick 1992). In many organisms, it belongs to a multigene family, in which genes are expressed in a developmental or tissue-specific manner.

On the other hand, suppression of MSX1 has increased the expression of various transcripts including meiosis-specific nuclear structural protein 1 (MNS1), $\beta$-galactoside-binding lectin ( $L G A L S 3)$, interferon $\tau 1$ (IFNT), ribosomal protein L23 (RPL23), placental 8 (PLAC8) and others. IFNT encodes a signalling protein secreted by the bovine conceptus during preimplantation period and is responsible for the recognition of pregnancy via preventing the pulsatile release of luteolytic PGF $2 \alpha$ (Ezashi \& Roberts 2004, Robinson et al. 2006). It is also important for the proliferation and distribution of peripheral blood lymphocyte subsets during one-way mixed lymphocyte reaction in cows and heifers (Gierek et al. 2006). According to Dai et al. (2004), RPL23 stimulates p53-dependent transcription and $G_{1}$ cell cycle arrest through binding to the murine double minute (MDM2) and inhibiting the MDM2mediated p53 degradation process. It also plays an important role in the ribosomal biogenesis-p53 pathway.

Functional characterization in cultured cell has indicated that MNS1 is a detergent and high salt-resistant skeletal protein, which is involved in the organization of the nuclear or pronuclear architecture, and is specifically expressed at the pachytene stage during spermatogenesis (Furukawa et al. 1994). LGALS3 is widely expressed in epithelial tissues, and has been implicated in a variety of cellular processes including adhesion and polarization. More specifically, it is required for optimal long-term cell adhesion to both collagen I and laminin 11 (Friedrichs et al. 2007).

The consensus pathway database enrichment analysis showed that genes differentially regulated due to suppression of bovine MSX1 to be enriched with two functional modules, namely checkpoint with forkhead and ring finger domains (CHFR), which interacts with Aurora A. The other module which is enriched with the MSX1 target genes (nucleolar protein 12 and Aurora A) is superoxide dismutase 2 (Fig. 9).

This study has generated some important data regarding the role of $M S X 1$ in bovine preimplantation embryo development. However, it has also few limitations. The difficulty to follow up the development of microinjected embryos during foetal development beyond blastocysts stage limits the application of such study to the in vivo system due to the transient RNAibased suppression effect. Secondly, although several 


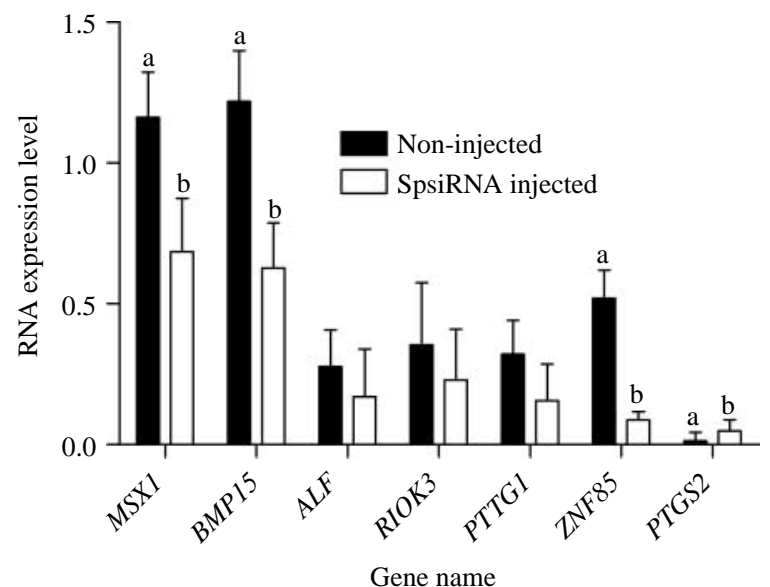

Figure 10 qRT-PCR validation of some of the differentially expressed transcripts between SpsiRNA-injected group and non-injected controls showing normalised (mean \pm s.E.M.) mRNA expression levels. The normalised mRNA expression values were obtained by dividing mRNA expression level of the candidate gene by that of the housekeeping gene, GAPDH.

genes were found to be differentially regulated due to suppression of MSX1, we believe that these might not be the only MSX1-dependent transcripts as the bovine cDNA array that was used in this study contains a limited number of clones. Moreover, because the bovine genome is not completely annotated, the predicted pathways in the present study might be incomplete due to missing genes and a number of differentially expressed genes are uncharacterised, their molecular functions are poorly understood and their association with MSX1 could not be established.

It is true that cellular response to mechanical injury could result in the misexpression of certain genes, and we believe that scRNA or nuclease-free water injected zygotes should have been included as negative controls in this microarray experiment, so that the reported differential gene expression can be attributed only to RNAi-mediated suppression of MSX1. However, the expected RNAi effect due to injection of the anti-sense oligomers cannot be completely ruled out as blastocyst rates in zygotes injected with scRNA were significantly different from those in zygotes injected with LdsRNA and siRNA. Interestingly, even though statistically nonsignificant (due to a narrow margin of the $P$ value), zygotic development to 8-cells in the scRNA-injected group was higher than that in SpsiRNA-injected groups, necessitating the need to consider the supposed biological implication.

The qRT-PCR showed that the mRNA expression of some of the differentially expressed genes was reduced compared with the non-injected controls but such differences appeared to be statistically non-significant. Although this is the case, the observed reduction in the mRNA expression level of these genes is believed to have significant biological effects as validated by protein expression data and the effect on oocyte maturation and cleavage rate due to suppression of MSX1. Additionally, the current gene expression data alone cannot be conclusive that the differentially expressed genes are targeted by MSX1. Therefore, there is a need for further
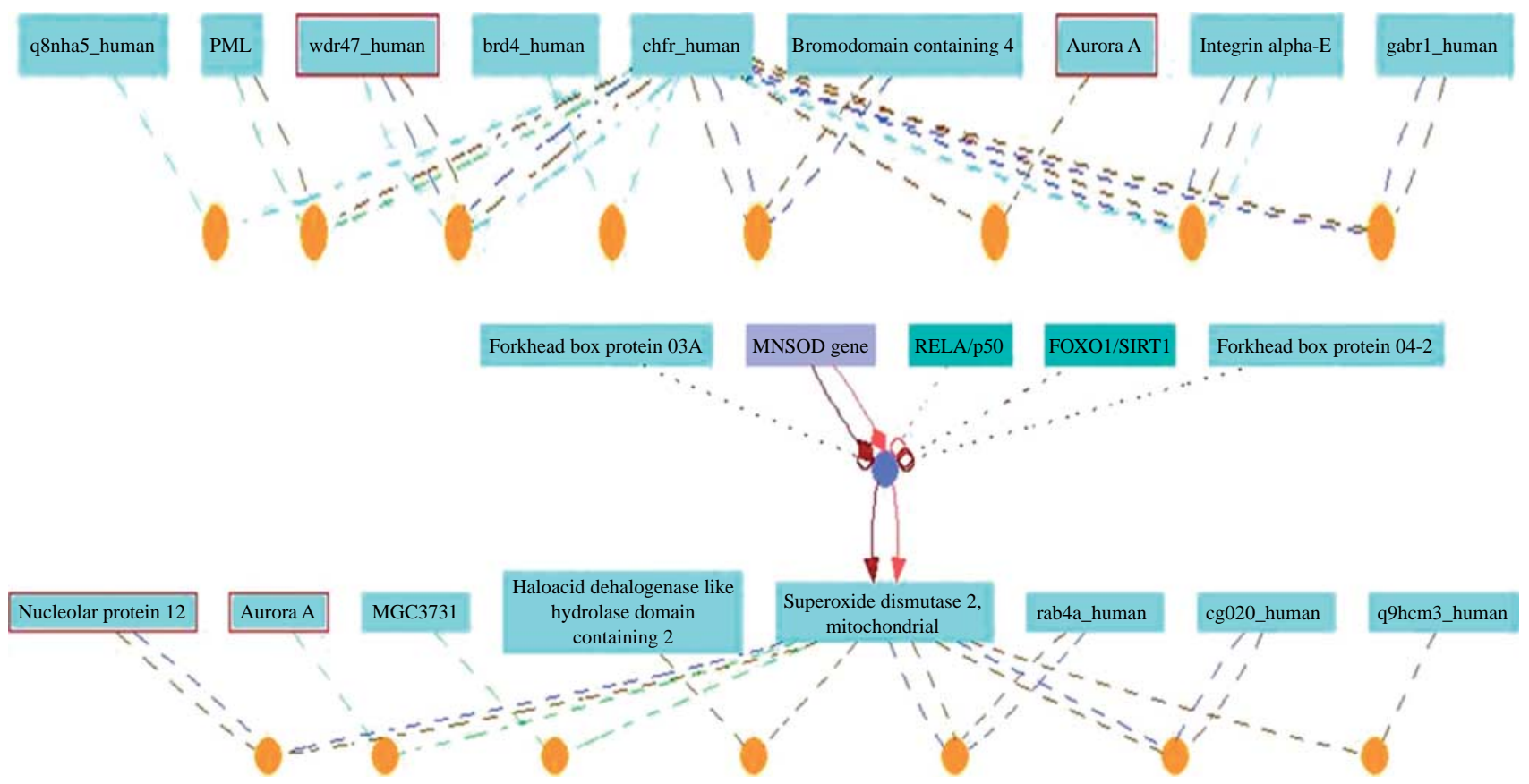

Figure 11 Two functional modules (A) NEST: CHFR, $P$ value $2.92 \times 10^{-6}$; (B) NEST: SOD2, $P$ value $1.25 \times 10^{-5}$ ) enriched by $M$ SX 1 target genes. Colour of nodes refers to the type of the interaction (blue, gene regulatory interaction; orange, protein-protein interaction), and edges refer to the different source databases that carry this information. Rectangles refer to the component entity types. 
manipulation of the key gene products in order to identify proteins/pathways that are involved in this phenomenon.

In conclusion, suppression of MSX1 affects oocyte maturation, embryo cleavage rate and potentially the expression of several genes, suggesting that it has a role in the development of bovine oocytes and preimplantation embryos.

\section{Materials and Methods Experimental design}

This study was conducted using four treatment groups in experiments 1 and 2 and two treatment groups in experiment 3 .

In experiment 1, microinjection of 341 bp LdsRNA, 19 bp siRNA and 19 bp scRNA was done at GV oocyte stage and developmental stage, and mRNA and protein expression data were collected at MII oocyte.

In experiment 2, microinjection of the same anti-sense oligomers was done at zygote stage. Development to 2-, 4- and 8-cells was assessed at $72 \mathrm{hpi}$, and that to blastocysts was assessed at 7 days post insemination. The mRNA expression level was determined at 8-cell stage, and protein expression was investigated at 2-, 4- and 8-cell stages.

In experiment 3, in order to investigate the cleavage rate of embryos and identify genes affected due to suppression of bovine MSX1, $10 \mu \mathrm{g} / \mu \mathrm{l}$ custom SpsiRNAs consisting of four different siRNAs (Dharmacon, Inc.) were used to microinject the zygotes, and large-scale gene expression analysis was performed at 8-cell stage using a BlueChip bovine cDNA array.

\section{Synthesis of long double-stranded RNA}

Pairs of primers (Table 5) were designed according to the bovine cDNA sequence found in gene bank using primer express software v 2.0 (Applied Bio Systems, Foster City, CA, USA) to amplify a fragment of bovine MSX1. Primer-generated PCR amplicon that corresponds to the coding sequence of MSX1 was identified, and the product was confirmed by sequencing. The first round of PCR was performed using thermocycler program at $95^{\circ} \mathrm{C}$ for 5 min followed by 40 cycles of denaturing at $95{ }^{\circ} \mathrm{C}$ for $30 \mathrm{~s}$ and annealed at $56^{\circ} \mathrm{C}$ for $30 \mathrm{~s}$. Extension was done at $72{ }^{\circ} \mathrm{C}$ for $1 \mathrm{~min}$, and a 10 -min elongation step at $72{ }^{\circ} \mathrm{C}$ was performed after the last cycle. The same procedure was repeated for the second round of PCR using T7 promoter (GTAATACGACTCACTATAGGG) attached to the $5^{\prime}$ end of each primer to generate two different templates for in vitro transcription of sense and anti-sense RNA strands. The DNA template coupled with T7 promoter was in vitro transcribed using RiboMaxTM large-scale RNA production systems (Promega), in which sense and anti-sense strands were transcribed from cDNA template in different reactions (Amdam et al. 2003). After in vitro transcription, the cDNA template was removed by digesting in RNase-free DNase at $37{ }^{\circ} \mathrm{C}$ for $15 \mathrm{~min}$. Subsequently, sense and anti-sense RNA strands were annealed by incubating the reaction at $37^{\circ} \mathrm{C}$ for $4 \mathrm{~h}$ to synthesise the LdsRNA (Wianny \& Zernicka 2000). Following phenol/chloroform extraction, the RNA was precipitated with $0.1 \mathrm{ml}$ of $3 \mathrm{M}$ sodium acetate $(\mathrm{pH} 5.2)$ and $2.5 \mathrm{ml}$ of $100 \%$ ethanol and was centrifuged at $800 \mathrm{~g}$ for $30 \mathrm{~min}$, and the resulting pellet was washed with $70 \%$ ethanol. Finally, the LdsRNA pellet was resuspended in $10 \mu \mathrm{l}$ nuclease-free water and concentration was measured. The LdsRNA was eluted in nuclease-free water

Table 5 Details of primers that were used for qRT-PCR quantification and long double-stranded RNA (LdsRNA) synthesis.

\begin{tabular}{|c|c|c|c|c|}
\hline Gene name & Accession number & Primer sequences & $\begin{array}{c}\text { Annealing } \\
\text { temperature }\left({ }^{\circ} \mathrm{C}\right)\end{array}$ & Product size (bp) \\
\hline$M S X 1 a$ & NM_174798 & $\begin{array}{l}\text { F: 5'-AAGGTATCCACAGTCCCCAGC-3' } \\
\text { R: 5'-TCTGCCTCTCCTGCAAAGTTC-3' }\end{array}$ & 58 & 150 \\
\hline$M S X 1 b$ & NM_174798 & $\begin{array}{l}\text { F: 5'-AGAAGCAGTACCTGTCCATCG-3' } \\
\text { R: 5'-GGCCTTCTATGTCAGGTGGTA-3' }\end{array}$ & 56 & 341 \\
\hline$M S X 1 c$ & NM_174798 & $\begin{array}{c}\text { F: 5'-GTAATACGACTCACTATAGGG } \\
\text { AGAAGCAGTACCTGTCCATCG-3' } \\
\text { R: 5'-GTAATACGACTCACTATAGGG } \\
\text { GGCCTTCTATGTCAGGTGGTA-3' }\end{array}$ & 57 & 190 \\
\hline$M S X 2$ & XM_592489 & $\begin{array}{l}\text { F: 5'-TCCCTTTCCСCATCAACTCTC-3' } \\
\text { R: 5'-AACAAACATCCATCCCGGAG-3' }\end{array}$ & 57 & 178 \\
\hline BMP15 & AY304484 & $\begin{array}{l}\text { F: 5'-CTGACGCAAGTGGACACCCTA-3' } \\
\text { R: } 5^{\prime} \text {-GACACACGAAGCGGAGTCGTA-3' }\end{array}$ & 60 & 396 \\
\hline PTTG1 & NM_004219 & $\begin{array}{l}\text { F: 5'-GAAGAGCACCAGATTGCGC-3' } \\
\text { R: 5'-GTCACAGCAAACAGGTGGCA-3' }\end{array}$ & 55 & 204 \\
\hline GAPDH & BC102589 & $\begin{array}{l}\text { F: 5'-ACCCAGAAGACTGTGGATGG-3' } \\
\text { R: 5'-ACGCCTGCTTCACCACCTTC-3' }\end{array}$ & 60 & 247 \\
\hline$A L F$ & NM_006872 & $\begin{array}{l}\text { F: 5'-CCTCTGCTTTGTGAATGGCA-3' } \\
\text { R: 5'-CGCATCAGCTCAAACCTGC-3' }\end{array}$ & 53 & 215 \\
\hline RIOK3 & NM_003831 & $\begin{array}{l}\text { F: 5'-CCTAATGCTGGCTCAGATGCT-3' } \\
\text { R: 5'-TCACGAGTGTCCTGCCAGTC-3' }\end{array}$ & 56 & 185 \\
\hline ZNF85 & ВC047646 & $\begin{array}{l}\text { F: 5'-GGCATCAAATCCTGGGTGTCT-3' } \\
\text { R: 5'-TGGTCACCTTTCTGGAGCAAA-3' }\end{array}$ & 54 & 105 \\
\hline PTGS2 & AF031698 & $\begin{array}{l}\text { F: 5'-GGAAATCCTCAGCTCAAAAC-3' } \\
\text { R: 5'-GTCTCCCTGGGAACTATTC-3' }\end{array}$ & 56 & 221 \\
\hline
\end{tabular}

MSX1a, primers that were used for real-time quantification of MSX1 mRNA; MSX1b, primers that were used for synthesis of LdsRNA; MSX1c, primers that were used for double-stranded DNA amplification. 
to obtain a final concentration of $25 \mathrm{ng} / \mu \mathrm{l}$ and was stored at $-80{ }^{\circ} \mathrm{C}$. The size and purity of the LdsRNA were evaluated on a $2 \%$ agarose gel electrophoresis.

\section{Oocyte recovery, in vitro maturation and IVF}

Bovine ovaries were collected from local slaughterhouse and transported to the laboratory within $2-3 \mathrm{~h}$ in a thermo flask containing $0.9 \%$ physiological saline solution $(\mathrm{NaCl})$ at $39{ }^{\circ} \mathrm{C}$. Subsequently, cumulus-oocyte complexes (COCs) were aspirated from follicles with a diameter of 2-8 $\mathrm{mm}$ using $5-\mathrm{ml}$ syringe attached to 18-gauge needle. COCs with evenly granulated cytoplasm and multiple layer of cumulus cell were picked using a glass pipette and washed three times in drops of modified parker's medium supplemented with $12 \%$ oestrus cow serum (OCS). COCs were cultured in groups of 50 in 400- $\mu$ l maturation medium under mineral oil (Sigma) in four-well dishes (Nunc, Roskilde, Denmark) for $22 \mathrm{~h}$ at $39{ }^{\circ} \mathrm{C}$ in an incubator with humidified atmosphere containing $5 \% \mathrm{CO}_{2}$. Based on the number of oocytes, 2-4 straws of semen collected from known breeding bull were thawed, and motile spermatozoa were obtained by swim-up procedure (Parish et al. 1998). After maturation, COCs were transferred into a four-well dish containing $400 \mu \mathrm{l}$ of fertilization medium (Fert-TALP) supplemented with $2 \mu \mathrm{g} / \mathrm{ml}$ heparin and $0.2 \mathrm{mM}$ pyruvate (Sigma), and $25 \mu \mathrm{l} / \mathrm{ml}$ peniclinamine hypotaurine adrenaline medium was added to each well to initiate sperm motility and was covered with mineral oil (Sigma). Finally, IVF was performed using $1 \times 10^{6}$ sperm cells for a group of 50 oocytes and co-incubated for $20 \mathrm{~h}$.

\section{In vitro culture of embryos}

Following IVF, presumed zygotes were gently vortexed to separate them from the surrounding cumulus cells and dead spermatozoa. Cumulus-free zygotes were washed three times and cultured in CR-1aa culture medium (Rosenkrans \& First 1994) supplemented with $10 \%$ OCS, $10 \mu \mathrm{l} / \mathrm{ml}$ BME (essential amino acids) and $10 \mu \mathrm{l} / \mathrm{ml} \mathrm{MEM} \mathrm{(non-essential} \mathrm{amino} \mathrm{acids)} \mathrm{for}$ 8 days at $39{ }^{\circ} \mathrm{C}$ in an incubator with humidified atmosphere containing $5 \% \mathrm{CO}_{2}$.

\section{Microinjection of oocytes and zygotes}

In addition to LdsRNA, $10 \mu \mathrm{g} / \mu \mathrm{l}$ siRNA 5'-GGG CCG AGU UCU CCA GUU CUU-3' 5'-GAA CUG GAG AAC UCG GCG CUU-3' and sCRNA $5^{\prime}$-GCC GCU GUU CUC GUA CGA CUU-3' 5'-GUC GUA CGA GAA CAG CGG CUU-3' (Eurofins MWG Operon, Ebersberg, Germany) were used for microinjection. COCs with compact and multiple layers of cumulus cells and evenly granulated cytoplasm were selected for microinjection (Leibfried \& First 1979) prior to partial removal of the surrounding cumulus cells to avoid difficulties during microinjections. Oocytes were held in Hepes-buffered Medium 199 supplemented with $0.1 \%$ BSA, $0.2 \mathrm{mM}$ pyruvate and $50 \mu \mathrm{g} / \mathrm{ml}$ gentamicin sulphate (Sigma) in a humidified atmosphere containing $5 \% \mathrm{CO}_{2}$ at $39^{\circ} \mathrm{C}$. Prior to injection, oocytes were incubated for $20 \mathrm{~min}$ in Hepes-buffered Medium 199 supplemented with $8 \mu \mathrm{g} / \mathrm{ml}$ cytochalasin B (Paradis et al. 2005). In four experimental sessions, a total of 1408 GV stage oocytes were randomly allocated to the four groups, namely non-injected controls $(n=298)$, scRNA injected $(n=367)$, LdsRNA injected $(n=376)$ and siRNA injected $(n=367)$. Zygotes were injected $20 \mathrm{~h}$ after fertilization. Microinjection was performed on an inverted microscope (NiKon TS-100) with a magnification of $200 \times$ by aspirating the RNAs into a $0.5-\mu \mathrm{m}$ diameter injection capillary (Femtojet II; Eppendorf, Hamburg, Germany). Injection volume of $\sim 7 \mathrm{pl}$ was estimated from the displacement of the meniscus of mineral oil in the capillary. After microinjections, oocytes from all groups were washed three times in CR-1aa medium, and set back into culture and checked for survival $1 \mathrm{~h}$ after injection.

In experiment 2, a total of 2352 zygotes were randomly allocated into four groups, namely non-injected controls ( $n=445)$, scRNA injected $(n=652)$, LdsRNA injected $(n=636)$ and siRNA injected $(n=619)$. In experiment 3 , in order to assess the effect of SpsiRNAs on the development of preimplantation embryos, additional pools of zygotes were injected with SpsiRNAs $(n=479)$, and scRNA $(n=497)$ and their cleavage rate were compared with non-injected control $(n=653)$. After assessing the effect of SpsiRNAs on the development of embryos, a total of 600 zygotes were microinjected (in three different microinjection sessions) using $10 \mu \mathrm{g} / \mu \mathrm{l}$ custom SpsiRNAs for global gene expression analysis. After injection, all groups of zygotes were washed three times in CR-1 aa medium, and set back into culture medium (Rosenkrans \& First 1994) supplemented with $10 \%$ OCS, $10 \mu \mathrm{l} / \mathrm{ml} \mathrm{BME}$ (essential amino acids) and $10 \mu \mathrm{l} / \mathrm{ml} \mathrm{MEM} \mathrm{(non-essential} \mathrm{amino}$ acids) for 8 days in experiment 2 and 72 hpi in experiment 3 at $39{ }^{\circ} \mathrm{C}$ in an incubator with humidified atmosphere containing $5 \% \mathrm{CO}_{2}$. The zygotes were checked for survival $2 \mathrm{~h}$ after injection, and cleavage rates were assessed at $72 \mathrm{hpi}$.

\section{Collection of oocytes and embryos}

In order to study the effects of the injected anti-sense oligomers on the relative abundance of the target mRNA and protein, oocytes and embryos were collected at specific time point after microinjection. In experiment 1, following phenotypic data collection, matured oocytes were frozen for mRNA and protein expression analysis $28 \mathrm{~h}$ post microinjection. In experiment 2 , zygotes were cultured until 8-cell (72 hpi) and day 8 blastocyst (7 days post insemination) stages to assess developmental phenotypes, mRNA and protein expression. Cumulus-free zygotes were washed twice and cultured in CR-1aa culture medium supplemented with 10\% OCS, $10 \mu \mathrm{l} / \mathrm{ml}$ BME (essential amino acids) and $10 \mu \mathrm{l} / \mathrm{ml}$ MEM (non-essential amino acids) for $72 \mathrm{hpi}$ at $39{ }^{\circ} \mathrm{C}$ in an incubator with humidified atmosphere containing $5 \% \mathrm{CO}_{2}$. Prior to freezing, all oocytes and zygotes were washed twice in PBS (Sigma) and $0.5 \%$ polyvinyl alcohol, and frozen in cryo-tubes containing lysis buffer and stored at $-80{ }^{\circ} \mathrm{C}$.

\section{RNA isolation and RT}

Three pools of biological replicates each containing $\sim 30 \mathrm{MII}$ oocytes and 24 8-cell stage embryos from each treatment group were used for mRNA isolation. mRNA was isolated using oligo 
(dT)25-attached magnetic beads (Dynal, Oslo, Norway) according to the manufacturer's instruction and as briefly described in our previous studies (Nganvongpanit et al. 2006a, 2006b). The isolated mRNAs were eluted in $11 \mu \mathrm{l}$ RNase-free water and reverse transcribed in $20 \mu \mathrm{l}$ of total reaction volume containing $1 \mu \mathrm{l}$ oligo (dT)25 primer, $4 \mu \mathrm{l}$ of $5 \times$ first-strand buffer $(375 \mathrm{mM} \mathrm{KCl}, 15 \mathrm{mM} \mathrm{MgCl} 2,250 \mathrm{mM}$ Tris- $\mathrm{HCl}, \mathrm{pH}$ 8.3), $2 \mu$ of dithiothreitol, $1 \mu \mathrm{l}$ dNTP, $0.3 \mu$ l RNase inhibitor (Promega) and $0.7 \mu \mathrm{l}$ of superscript II RT (Invitrogen). The mRNA and oligo(dT)25 primer were incubated at $70{ }^{\circ} \mathrm{C}$ for $3 \mathrm{~min}$ and placed on ice until the remaining reaction components were added. The reactions were incubated at $42{ }^{\circ} \mathrm{C}$ for $90 \mathrm{~min}$ and terminated by heat inactivation at $70{ }^{\circ} \mathrm{C}$ for $15 \mathrm{~min}$.

\section{Quantification of mRNA levels using qRT-PCR}

The ABI prism 7000 apparatus (Applied Biosystems) was used to perform the quantitative analysis using SYBR Green incorporation for dsDNA-specific fluorescent detection dye. For this, both MSX1 and MSX2 genes were quantified using sequence-specific primers. Standard curves were fitted for both target and internal control gene, $G A P D H$, using serial dilutions of plasmid DNA containing $10^{1}-10^{9}$ molecules and were run in separate wells. During each reaction, samples from the same cDNA were run in duplicate to control the reproducibility of the results. Final quantitative analysis was done using the relative standard curve method, and the results were reported as the relative expression level compared to non-injected controls after normalization of the transcript level using the internal control gene. Finally, the suppression levels of the target mRNA due to microinjection of anti-sense oligomers were reported as mean percentage values using the noninjected control group as calibrator, for which the mRNA expression value was assigned 1 or $100 \%$.

\section{Statistical analysis}

The normalised mRNA expression and developmental data were analysed by ANOVA, and the mean values were compared for statistical significance using Tukey test (SPSS Inc., Chicago, IL, USA). Differences were considered statistically significant at $P \leq 0.05$.

\section{Immunofluorescence staining}

MII oocytes were obtained after $22 \mathrm{~h}$ in vitro maturation of GV stage oocytes and zygotes, 2-, 4- and 8-cells were collected at 20, 32, 48 and 72 hpi respectively for immunofluorescence staining. Ten individual MII oocytes, zygotes, 2-, 4- and 8-cell stage embryos from each treatment group were washed three times in PBS and fixed in $4 \%(\mathrm{w} / \mathrm{v})$ paraformaldehyde overnight at $4{ }^{\circ} \mathrm{C}$. The fixed specimens were permeabilised during 2.5-h incubation in $0.5 \%(\mathrm{v} / \mathrm{v}$ ) Triton-X100 (Sigma) in PBS. In order to inhibit non-specific binding of the antibodies, samples were subsequently blocked in $3 \%(\mathrm{w} / \mathrm{v})$ BSA in PBS for $1 \mathrm{~h}$. The oocytes and embryos were then incubated for $1 \mathrm{~h}$ at $39^{\circ} \mathrm{C}$ with 1:100 dilution of rabbit anti-human polyclonal MSX1 primary antibody (Lifespan Biosciences, Inc., Seattle, WA, USA).
Oocytes and embryos were washed three times in PBS and further incubated for $1 \mathrm{~h}$ with $100 \times$ diluted FITC-conjugated anti-rabbit IgG secondary antibody (Sigma). Negative controls were processed in the same manner by omitting the use of primary antibody. In order to visualise the nucleus of the cell, oocytes and embryos were finally incubated in $0.5 \mathrm{mg} / \mathrm{ml}$ propidium iodide (Sigma). After the final wash in PBS, oocytes and embryos were mounted on glass slides and visualised on a confocal laser scanning microscope (CLSM LSM-510; CarlZeiss, Jena, Germany).

\section{Large-scale gene expression analysis}

RNA amplification

In order to identify the differentially expressed genes due to suppression of $M S X 1$, large-scale gene expression analysis was done using a BlueChip bovine cDNA array (Sirard et al. 2005). First- and second-strand cDNAs were synthesised as described in our previous study (El-Sayed et al. 2006). Ten amplification cycles were used during second-strand cDNA synthesis to increase the representativeness of the original RNA population after in vitro transcription. The synthesised cDNA was then purified and used for in vitro transcription using AmpliScribe T7 transcription kit (Epicentre Technologies, Oldendorf, Germany) according to the manufacturer's instructions. Then, the amplified RNA (aRNA) was purified using RNeasy Mini kit (Qiagen) and eluted in $30 \mu \mathrm{l}$ RNase-free water, from which $8 \mu \mathrm{l}$ were taken to estimate the yield and purity of aRNA through gel electrophoresis and spectrophotometric analysis at A260/280 using Ultrospec 2100 pro u.v./Visible Spectrophotometer (Amersham Bioscience).

\section{Aminoallyl labelling and dye coupling}

Minimum Information About Microarray Experiments guidelines were followed in the experimental design. Two independent labelling reactions were carried out per aRNA sample pertinent to each biological replicate for dye-swap hybridizations. Accordingly, $3 \mu \mathrm{g}$ of aRNA from each pool of 8-cell embryos were used as a template in $\mathrm{RT}$ reactions incorporating amino-modified dUTPs into the cDNA using the CyScribe PostLabelling Kit (Amersham Biosciences) as described previously (El-Sayed et al. 2006). The cDNA samples from each treatment groups were differentially labelled indirectly using $\mathrm{N}$-hydroxysuccinate-derived Cy 3 and Cy 5 dyes and incubated for $1.5 \mathrm{~h}$ at room temperature in darkness. At the end of incubation, nonreactive dyes were quenched by adding $15 \mu \mathrm{l}$ of $4 \mathrm{M}$ hydroxylamine solution (Sigma) and incubated for $15 \mathrm{~min}$ at room temperature in darkness. To avoid variation due to dye coupling, aRNA samples from the same treatment group were labelled reversibly with either Cy3 or Cy5 for dye-swap hybridizations.

\section{Probe hybridization, scanning and data analysis}

Pre-hybridization of the slides was performed by placing the array slides into a corning GAPS II slide container as described in El-Sayed et al. (2006). Hybridization and post-hybridization 
procedures and washes were carried out as previously described elsewhere (Hegde et al. 2000) with slight modifications as indicated in our previous report (Ghanem et al. 2007). The slides were scanned using Axon GenePix 4000B scanner (Axon Instruments, Foster City, CA, USA). The GenePix Pro 4.0 software (Axon Instruments) was used to capture the images, find spots, integrate robot-spotting files and finally create reports of spot intensity data. LOWESS normalization of microarray data was performed using GProcessor 2.0a software (http://bioinformatics.med.yale.edu/group). The normalised data were used to calculate the intensity ratios of all replicates and to obtain one value per clone. Ratios were finally transformed to $\log 2$ and submitted to significance analysis for microarray (SAM). The resulting data were analysed using SAM software (http://www-stat.stanford.edu/ tibs/SAM). The true differential expression of genes was validated at false discovery rate $<5 \%$ and $P$ value $<0.05$, and a clone with a fold change value $\geq 1.5$ in the microinjection treatment groups compared with the controls was considered differentially expressed.

\section{Custom array characterization}

BlueChip bovine cDNA array (Sirard et al. 2005) with 2000 clones representing known genes and expressed sequence tags was used in this study. The glass slide contains 4928 spots divided into two sub-arrays. Each sub-array is composed of 2304 randomly selected clones obtained from four different subtraction suppressive hybridizations ( $\mathrm{SSHs}$ ) made using bovine embryos and tissues (First SSH: GV oocytes subtracted from somatic tissues, second SSH: GV oocytes subtracted from day 8 blastocysts, third SSH: day 8 blastocysts subtracted from GV oocytes and fourth SSH: day 8 blastocysts subtracted from somatic tissues). All the clones were spotted in each sub-array using four replicates per slide. Eleven more samples namely empty (32 spots), alien 1 (8 spots), alien 2 (8 spots), GFP (4 spots), GFP1 (4 spots), GFP1/2 (4 spots), GFP1/4 (4 spots), GFP1/8 (4 spots), GFP 1/16 (4 spots) and H20/DMSO (50 spots) were spotted to be used as negative controls for determination of hybridization background during the statistical analysis. Housekeeping genes including tubulin (8 spots), ubiquitin ( 8 spots), $\beta$-actin ( 6 spots) and actin ( 8 spots) were also added as positive controls.

\section{Identification of functional modules}

Enrichment analysis of MSX1 target genes with respect to functional modules was performed with the Consensus Pathway Database which integrates the content of twelve different pathways and interaction databases that carry information of various heterogeneous levels of information such as signalling, protein-protein interactions and metabolic reactions (http://cpdb.molgen.mpg.de). Interactions were mapped to each other by identifier mapping (Kamburov et al. 2009). Functional modules were identified by creating gene sets (NESTs) from the integrated interaction graph. Significance of enrichment with respect to set of NESTs was judged with $\mathrm{p}$-values derived from the hypergeometric distribution.

\section{Supplementary data}

This is linked to the online version of the paper at http://dx.doi. org/10.1530/REP-09-0312.

\section{Declaration of interest}

The authors declare that there is no conflict of interest that could be perceived as prejudicing the impartiality of the research reported.

\section{Funding}

This research did not receive any specific grant from any funding agency in the public, commercial or profit making sector.

\section{Acknowledgements}

BlueChip preimplantation-specific bovine cDNA array was kindly provided by Dr Marc-André Sirard, University of Laval, Quebec, Canada.

\section{References}

Amdam G, Simões Z, Guidugli KR, Norberg K \& Omholt SW 2003 Disruption of vitellogenin gene function in adult honey bees by intraabdominal injection of double-stranded RNA. BMC Biotechnology 3 $1-8$.

Bao S, Obata Y, Ono Y, Futatsmata N, Niimura S \& Konto T 2002 Nuclear competence for maturation and pronuclear formation in mouse oocytes. Human Reproduction 17 1311-1316.

Bendall AJ \& Abate-Shen C 2000 The roles of Msx and Dlx homeo proteins in vertebrate development. Gene 247 17-31.

Catron KM, Wang H, Hu G, Shen M \& Abate-Shen C 1996 Comparison of Msx1 and Msx2 suggests a molecular basis for functional redundancy. Mechanisms of Development 55 185-199.

Chen Y, Bei M, Woo I, Satokata I \& Maas R 1996 Msx1 controls inductive signalling in mammalian tooth morphogenesis. Development 122 3035-3044.

Dai MS, Zeng SX, Jin Y, Sun XX, David L \& Lu H 2004 Ribosomal protein L23 activates p53 by inhibiting MDM2 function in response to ribosomal perturbation but not to translation inhibition. Molecular Cell Biology 24 7654-7668.

Davidson EH 1986 Gene Activity in Early Development, edn 3, pp 670. New York: Academic press.

Davidson D 1995 The function and evolution of Msx genes: pointers and paradoxes. Trends in Genetics 11 405-411.

Davidson DR \& Hill RE 1991 Msh-like genes: a family of homeobox genes with wide ranging expression during vertebrate development. Developmental Biology 2 405-412.

Davis GH, McEwan JC, Fennessy PF, Dodds KG \& Farquhar PA 1991 Evidence for the presence of a major gene influencing ovulation rate on the X chromosome of sheep. Biology of Reproduction 44 620-624.

Di Pasquale E, Beck-Peccoz P \& Personi L 2004 Hypergonadotropic ovarian failure associated with an inherited mutation of human bone morphogenetic protein-15 (BMP15) gene. American Journal of Human Genetics 75 106-111.

Donnison M \& Pfeffer P 2004 Isolation of genes associated with developmentally competent bovine oocytes and quantitation of their levels during development. Biology of Reproduction 71 1813-1821.

El-bashir S, Harborth J, Lendeckel W, Yalcin A, Weber K \& Tuschl T 2001 Duplexes of 21-nucleotide RNAs mediate RNA interference in cultured mammalian cell. Nature 411 494-498. 
EI-Sayed A, Hoelker M, Rings F, Salilew D, Jennen D, Tholen E, Sirard MA, Schellander K \& Tesfaye D 2006 Large-scale transcriptional analysis of bovine embryo biopsies in relation to pregnancy success after transfer to recipients. Physiological Genomics 28 84-96.

Elvin JA, Yan C \& Matzuk MM 2000 Oocyte-expressed TGF- $\beta$ super family members in female fertility. Molecular and Cellular Endocrinology 159 $1-5$.

Eyestone WH \& First NL 1986 A study of the 8- to 16-cell developmental block in bovine embryos cultured in vitro. Theriogenology 25 152-160.

Ezashi T \& Roberts RM 2004 Regulation of interferon-tau (IFN-tau) gene promoters by growth factors that target the Ets-2 composite enhancer: a possible model for maternal controls of IFN-tau production by the conceptus during early pregnancy. Endocrinology 145 4452-4460.

Fire A, Xu S, Montgomery MK, Kostas SA, Driver SE \& Mello CC 1998 Potent and specific genetic interference by double-stranded RNA in Caenorhabditis elegans. Nature 391 806-811.

Frei RE, Schultz GA \& Church RB 1989 Qualitative and quantitative changes in protein synthesis occur at the 8-16-cell stage of embryogenesis in the cow. Journal of Reproduction and Fertility $\mathbf{8 6} 637-641$.

Friedrichs J, Torkko JM, Helenius J, Teräväinen TP, Füllekrug J, Muller DJ, Simons K \& Manninen A 2007 Contributions of galectin-3 and -9 to epithelial cell adhesion analyzed by single cell force spectroscopy. Journal of Biological Chemistry 282 29375-29383.

Furukawa K, Inagaki H, Naruge T, Tabata S, Tomida T, Yamaguchi A, Yoshikuni M, Nagahama Y \& Hotta Y 1994 cDNA cloning and functional characterization of a meiosis-specific protein (MNS1) with apparent nuclear association. Chromosome Research 2 99-113.

Galloway SM, McNatty KP, Cambridge LM, Laitinen MP, Juengel JL, Jokiranta TS, McLaren RJ, Luiro K, Dodds KG, Montgomery GW et al. 2000 Mutations in an oocyte-derived growth factor gene (BMP15) cause increased ovulation rate and infertility in a dosage-sensitive manner. Nature Genetics 25 279-283.

Ghanem N, Hölker M, Rings F, Jennen D, Tholen E, Sirard MA, Torner H, Kanitz W, Schellander K \& Tesfaye D 2007 Alterations in transcript abundance of bovine oocytes recovered at growth and dominance phases of the first follicular wave. BMC Developmental Biology 790.

Gierek D, Baczyńska D, Ugorski M, Bazer F, Kurpisz M, Bednarski T, Gorczykowski M \& Chełmońska-Soyta A 2006 Differential effect of IFNtau on proliferation and distribution of lymphocyte subsets in one-way mixed lymphocyte reaction in cows and heifers. Journal of Reproductive Immunology 71 126-131.

Gomes WA \& Kessler JA 2001 Msx2 and P21 mediate the pro-apoptotic but not the anti-proliferative effects of BMP4 on cultured sympathetic neuroblasts. Developmental Biology 237 212-221.

Graham A, Heyman I \& Lumsden A 1993 Even-numbered rhombomeres controls the apoptotic elimination of neural crest cell from oddnumbered rhombomeres in the chick hindbrain. Development 119 233-245.

Graham A, Francis-West P, Brickell P \& Lumsden A 1994 The signalling molecule BMP4 mediates apoptosis in the rhombencephalic neural crest. Nature 372 684-686.

Graham A, Koentges G \& Lumsden A 1996 Neural crest apoptosis and the establishment of craniofacial pattern: an honorable death. Molecular and Cellular Neurosciences 8 76-83.

Hamid T \& Kakar SH 2004 PTTG/securin activates expression of p53 and modulates its function. Molecular Cancer 318.

Han S, Xie W, Hammes SR \& Dejong J 2003 Expression of the germ cell-specific transcription factor ALF in Xenopus oocytes compensates for translational inactivation of the somatic factor TFIIA. Journal of Biological Chemistry 278 45586-45593.

Hanrahan JP, Gregan SM, Mulsant P, Mullen M, Davis GH, Powell R \& Galloway SM 2004 Mutations in the genes for oocyte-derived growth factors GDF9 and BMP15 are associated with both increased ovulation rate and sterility in Cambridge and Belclare sheep (Ovis aries). Biology of Reproduction 70 900-909.

Hegde P, Qi R, Abernathy R, Gay C, Dharap S, Gaspard R, Earle-Hughes J, Snesrud E, Lee NH \& Quackenbush J 2000 A concise guide to CDNA microarray analysis. BioTechniques 29 548-550.

Holen T, Amarzguioui M, Wiiger MT, Babaie E \& Prydz H 2002 Positional effects of short interfering RNAs targeting the human coagulation trigger tissue factor. Nucleic Acids Research 30 1757-1766.
Hu X, Hipolito S, Lynn R, Abraham V, Ramos S \& Wong-Staal F 2004 Relative gene silencing efficiencies of small interfering RNAs targeting sense and antisense transcripts from the same genetic locus. Nucleic Acids Research 32 4609-4617.

Ishiwata H, Katsuma S, Kizaki K, Patel OV, Nakano H, Takahashi T, Imai K, Hirasawa A, Shiojima S, Ikawa $\mathbf{H}$ et al. 2003 Characterization of gene expression profiles in early bovine pregnancy using a custom cDNA micro array. Molecular Reproduction and Development 65 9-18.

Juengel JL, Hudson NL, Whiting L \& McNatty KP 2004 Effects of immunization against bone morphogenetic protein 15 and growth differentiation factor 9 on ovulation rate, fertilization, and pregnancy in ewes. Biology of Reproduction 70 557-561.

Kamburov A, Wierling C, Lehrach H \& Herwig R 2009 Consensus PathDB: a database for integration of human functional interactions. Nucleic Acids Research 37 D623-D628.

Kopency V, Flechon JE, Camous S \& Fulka JR 1989 Nucleologenesis and the onset of transcription in the eight-cell bovine embryo: fine-structural autoradiographic study. Molecular Reproduction and Development 1 79-90.

Kruip TA, Cran DG, Van Beneden TH \& Dieleman SJ 1983 Structural changes in bovine oocytes during final maturation in vivo. Gamete Research 8 29-47.

Lazzari G, Colleoni S, Giannelli SG, Brunetti D, Colombo E, Lagutina I, Galli C \& Broccoli V 2006 Direct derivation of neural rosettes from cloned bovine blastocysts: a model of early neurulation events and neural crest specification in vitro. Stem Cells 24 2514-2521.

Leibfried ML \& First NL 1979 Characterization of bovine follicular oocytes and their ability to mature in vitro. Journal of Animal Science $\mathbf{4 8} 76$.

Li T, Chang C, Jin D, Lin P, Khvorova A \& Stafford DW 2004 Identification of the gene for vitamin K epoxide reductase. Nature 427 541-544.

Luther JS, Redmer DA, Reynolds LP, Choi JT, Pant D, Navanukraw C, Arnold DR, Scheaffer AN, Borowicz P, Kirsch JD et al. 2005 Ovarian follicular development and oocyte quality in anestrous ewes treated with melatonin, and controlled internal drug release (CIDR) device and follicle stimulating hormone. Theriogenology 63 2136-2146.

Marazzi G, Wang Y \& Sassoon D 1997 Msx2 is a transcriptional regulator in the BMP4-mediated programmed cell death pathway. Developmental Biology 186 127-138.

McNatty KP, Juengel JL, Wilson T, Galloway SM, Davis GH, Hudson NL, Moeller CL, Cranfield M, Reader KL, Laitinen MP et al. 2003 Oocytederived growth factors and ovulation rate in sheep. Reproduction Supplement 61 339-351.

Memili E \& First NL 1999 Controls of gene expression at the onset of bovine embryonic development. Biology of Reproduction 61 1198-1207.

Memili E \& First NL 2000 Zygotic and embryonic gene expression in cow: a review of timing and mechanisms of early gene expression as compared with other species. Zygote 8 87-96.

Memili E, Dominko T \& First NL 1998 Onset of transcription in bovine oocytes and preimplantation embryos. Molecular Reproduction and Development 51 36-41.

Merrick WC 1992 Mechanism and regulation of eukaryotic protein synthesis. Microbiology and Molecular Biology Reviews 56 291-315.

Nganvongpanit K, Muller H, Rings F, Gilles M, Jennen D, Holker M, Tholen E, Schellander K \& Tesfaye D 2006a Targeted suppression of E-cadherin gene expression in bovine preimplantation embryo by RNA interference technology using double-stranded RNA. Molecular Reproduction and Development 73 153-163.

Nganvongpanit K, Muller H, Rings F, Holker M, Jennen D, Tholen E, Havlicek V, Bessenfelder U, Schellander K \& Tesfaye D 2006b Selective degradation of maternal and embryonic transcripts in vitro produced bovine oocytes and embryos using sequence specific double-stranded RNA. Reproduction 131 861-874.

Pant D, Reynolds LP, Luther JS, Borowicz PP, Stenbak T, Bilski JJ, Weigl RM, Lopes F, Johnson ML, Redmer DA et al. 2005 Expression of connexin 43 and gap junctional intercellular communication in cumulus oocyte complex in sheep. Reproduction 129 191-200.

Paradis F, Vigneault C, Robert C \& Sirard MA 2005 RNA interference as a tool to study gene function in bovine oocytes. Molecular Reproduction and Development 70 111-121.

Parish JJ, Susko-Parrish J, Winer MA \& First NL 1998 Capacitating of bovine sperm by heparin. Biology of Reproduction 38 1171-1180. 
Pavlova A, Boutin E, Cunha G \& Sassoon D 1994 Msx1 (Hox-7.1) in the adult mouse uterus: cellular interactions underlying regulation of expression. Development 120 335-345.

Plachot M \& Mandelbaum J 1990 Oocyte maturation, fertilization and embryonic growth in vitro. British Medical Bulletin 3 675-694.

Prigent C \& Giet R 2003 Aurora A and mitotic commitment. Cell 114 531-532.

Robinson RS, Fray MD, Wathes DC, Lamming GE \& Mann GE 2006 In vivo expression of interferon tau mRNA by the embryonic trophoblast and uterine concentrations of interferon tau protein during early pregnancy in the cow. Molecular Reproduction and Development 73 470-474.

Rosenkrans CF Jr \& First NL 1994 Effect of free amino acids and vitamins on cleavage and developmental rate of bovine zygotes in vitro. Journal of Animal Science 72 434-437.

Sato E, Matsuo M \& Miyamoto H 1990 Meiotic maturation of bovine oocytes in vitro: improvement of meiotic competence by dibutyryl cyclic adenosine 3,5'- monophosphate. Journal of Animal Science 68 1182-1187.

Shimasaki S, Moore RK, Otsuka F \& Erickson GF 2004 The bone morphogenetic protein system in mammalian reproduction. Endocrine Reviews 25 72-101.

Sirard MA, Dufort I, Vallee M, Massicotte L, Gravel C, Reghenas H, Watson AJ, King WA \& Robert C 2005 Potential and limitations of bovine-specific arrays for the analysis of mRNA levels in early development: preliminary analysis using a bovine embryonic array. Reproduction, Fertility, and Development 17 47-57.

Song K, Wang Y \& Sassoon D 1992 Expression of Hox-7.1 in myoblasts inhibits terminal differentiation and induces cell transformation. Nature 360 477-481.

Telford NA, Watson AJ \& Schultz GA 1990 Transition from maternal to embryonic controls of development: a comparison of several species. Molecular Reproduction and Development 26 90-100.
Tesfaye D, Lonergan P, Hoelker M, Rings F, Nganvongpanit K, Havlicek V, Besenfelder U, Jennen D, Tholen E \& Schellander K 2007 Suppression of connexin 43 and E-cadherin transcripts in in vitro derived bovine embryos following culture in vitro or in vivo in the homologous bovine oviduct. Molecular Reproduction and Development 74 978-988.

Udayakumar TS, Belakavadi M, Choi KH, Pandey PK \& Fondell JD 2006 Regulation of Aurora-A kinase gene expression via GABP recruitment of TRAP220/MED1. Journal of Biological Chemistry 281 14691-14699.

Vigneron C, Perreau C, Dupont J, Uzbekova S, Prigent C \& Mermillod P 2004 Several signaling pathways are involved in the control of cattle oocyte maturation. Molecular Reproduction and Development 69 $466-474$.

Wianny F \& Zernicka G 2000 Specific interference with gene function by double stranded RNA in early mouse development. Nature Cell Biology $270-75$.

Xu KP \& Greve T 1988 A detailed analysis of early events during in vitro fertilization of bovine follicular oocytes. Journal of Reproduction and Fertility 82 127-134.

Yao Y-Q, Xu J-S, Lee WM, Yeung WSB, Timothy PL \& Lee K-F 2003 Identification of mRNAs that are up-regulated after fertilization in the murine zygote by suppression subtractive hybridization. Biochemical and Biophysical Research Communications 304 60-66.

Received 29 July 2009

First decision 4 September 2009

Revised manuscript received 6 January 2010

Accepted 22 February 2010 